\title{
Chemical composition, antioxidant and antibacterial activities of extracts from Schinus molle wood branch growing in Egypt
}

\author{
Mohamed Z. M. Salem ${ }^{1}$ Mohamed Z. Zayed ${ }^{1} \cdot$ Hayssam M. Ali ${ }^{2,3}$ • \\ Mamoun S. M. Abd El-Kareem ${ }^{4}$
}

Received: 6 April 2016/Accepted: 17 August 2016/Published online: 20 September 2016

(C) The Japan Wood Research Society 2016

\begin{abstract}
In the present work, for the first time, the chemical components of essential oils (EOs) and extracts from wood branch (WB) resulted from the tree pruning wastes of Schinus molle L. grown in Egypt were evaluated for their antioxidant and antibacterial activities. EOs, methanol (ME), dichloromethane (DCME) and water (WE) extracts as antioxidant and antibacterial activities were measured. Total phenolic and flavonoid contents as well as analysis of extracts by gas chromatography-mass spectrometry (GC-MS) were reported. The major components in EOs were $\alpha$-elemol, $\beta$-pinene, and $\alpha$-phellandrene, in ME were 6-(4-chlorophenyl)-3-cyano-4-( $N$-benzylpiperazino)-2H-pyran-2-one, and 2-naphthalene methanol, decahydro- $\alpha, \alpha, 4 a-$ trimethyl-8-methylene, in DCME were 12-methyl-E,E-3,13-octadecadien-1-ol, and 1,2-benzenedicarboxylic acid, dioctyl ester, and in WE were $\beta$ eudesmol, and (Z,Z,Z)-9,12,15-octadecatrienoic acid, 2,3dihydroxypropyl ester. The highest total antioxidant activity was found with EOs $(90 \pm 1.23 \%)$ and WE $(86.30 \pm 1.40 \%)$. The lowest $\mathrm{IC}_{50}$ values of
\end{abstract}

Mohamed Z. M. Salem

zidan_forest@yahoo.com; mohamed-salim@alexu.edu.eg

1 Forestry and Wood Technology Department, Faculty of Agriculture (EL-Shatby), Alexandria University, Aflaton St., El-Shatby, P.O. Box 21545, Alexandria, Egypt

2 Botany and Microbiology Department, College of Science, King Saud University, P.O. Box 2455, Riyadh 11451, Saudi Arabia

3 Timber Trees Research Department, Sabahia Horticulture Research Station, Horticulture Research Institute, Agriculture Research Center, Alexandria, Egypt

4 Atomic and Molecular Physics Unit, Experimental Nuclear Physics Department, Nuclear Research Centre, Egyptian Atomic Energy Authority, Inshas, Cairo, Egypt
$13.11 \pm 3.00$, and $12.66 \pm 2.15 \mu \mathrm{g} / \mathrm{mL}$ were found with WE and EOs, respectively. EOs and WE were observed to have good antibacterial activity against Bacillus subtilis, Bacillus cereus, Staphylococcus aureus, Escherichia coli, Sarcina lutea, Pseudomonas aeruginosa, and Micrococcus luteus. In conclusion, the Schinus molle L. WB EOs and extracts might, indeed, be used as a potential source for pharmaceutical or food industries.

Keywords Schinus molle L. · Wood branch · Extracts · Antioxidant activity · Antibacterial activity

\section{Introduction}

Pepper tree (Schinus molle L.), belonging to the family Anacardiaceae, is frequently grown as an ornamental tree in Mediterranean region, and originated from South America and its habitat ranged from southern Brazil to Chile and Mexico [1-3]. Fresh leaves and fruits (berries) essential oils (EOs) have been shown to have a significant activity against the growth of some bacterial and fungal strains [3-9]. Other biological effects like antitumor, antiinflammatory, and antispasmodic have been reported [10-12].

Ethnopharmacologically, the tree is widely used in traditional medicine to treat a variety of diseased conditions including colds, asthma, coughs, diarrhea and dysentery, hemorrhage, laryngalgia, laryngitis, sore throat, spasm, trachagia and vermifuge [13]. Pepper tree is one of the medicinal plants traditionally used in many Brazilian medical literature for folk medicine [10, 14]. Various parts of this plant have been traditionally used to treat various diseases such as ulcers, respiratory problems, wounds, rheumatism, gout, diarrhea, skin disease, toothache, 
rheumatism, menstrual disorders, and respiratory and urinary tract infection [10, 14].

Schinus molle L. extracts have been used as topical antiseptic, antibacterial, antiviral, antifungal, anti-inflammatory, antioxidant, antitumor, astringent, antispasmodic, digestive stimulant, tonic, wound healing, diuretic, an analgesic agent, a stimulant and an antidepressant $[10,14]$.

$\alpha$-phellandrene and $\beta$-phellandrene were found as the main constituents in the leaf EOs of Schinus molle L. grown in Tunisia [15], and Turkey [16], bicyclogermacrene from leaf EOs of Schinus molle L. grown in Uruguay [17]. Limonene, (E)-caryophyllene, and bicyclogermacrene were reported as major components from the EOs of aerial parts (leaves and twigs) of Schinus molle L. grown in Southern Brazil [18], and in Tunisia, $\alpha$-phellandrene, $\beta$-phellandrene, and $\beta$-pinene were reported as major components from berries EOs [3].

There are few studies on the chemical composition of Schinus molle L. extracts and most of them refer to EOs from leaves, aerial parts and fruits, while the information on chemical components of wood branch (WB) and their biological activity are still not determined. In our continuing research on the biological activities of Egyptian medicinal higher plants, as well as to the best of our knowledge, since no information is available on the chemical composition of WB resulted from the tree pruning wastes of Schinus molle L. grown in Egypt, the present study was carried out to evaluate the EOs, methanol, dichloromethane and water extracts for antioxidant and antibacterial activities. The total phenolic and flavonoid contents as well as analysis of extracts by gas chromatography-mass spectrometry (GC-MS) were reported.

\section{Materials and methods}

\section{Branches of Schinus molle L. and essential oils preparation}

Fresh branches resulted from the tree pruning wastes of Schinus molle L. were collected from Alexandria, Egypt, in the middle of September 2013, and the laboratory work was completed at the end of 2015. The plant was identified at the Department of Forestry and Wood Technology and with the voucher No. Zidan00310. Bark was removed and wood was cut into small pieces $(100 \mathrm{~g})$ and then hydrodistillated for $3 \mathrm{~h}$ [8]. The oil was dried over anhydrous $\mathrm{Na}_{2} \mathrm{SO}_{4}$, and measured with respect to fresh weight of WB $(0.75 \mathrm{~mL} / 100 \mathrm{~g}$ fresh weight). The oil was kept dry in sealed Eppendorf tubes and stored at $4{ }^{\circ} \mathrm{C}$ until used for GC-MS analysis and biological activity tests.

\section{Preparation of extracts}

One hundred grams of air-dried powder of WB was used for the extraction for each of the following solvents: methanol, dichloromethane, and water. About $250 \mathrm{~mL}$ of each solvent was poured in a 500-mL conical flask containing the air-dried WB and covered with cotton wool plug and wrapped with aluminum foil. Extraction was allowed to proceed for $48 \mathrm{~h}$ under laboratory conditions. The extracts were filtered using filter paper Whatman No. 1 , and then, the solvents were evaporated to dryness using a rotary evaporator. The yields for methanol (ME), dichloromethane (DCME) and water (WE) extracts were 15.12, 17.05; and $21.30 \mathrm{~g} / 100$ air-dried samples, respectively. All the extracts were kept dry in sealed brown vials and stored at $4{ }^{\circ} \mathrm{C}$ until used for GC/MS analysis and biological activity tests.

\section{GC-MS analysis}

\section{GC-MS analysis of the essential oils}

GC Ultra/Mass spectrophotometer ISQ (Thermo Scientific), a trace instrument equipped with FID and DB-5 narrow bore column (length $10 \mathrm{~m} \times 0.1 \mathrm{~mm}$ ID, $0.17 \mu \mathrm{m}$ film thickness; Agilent, Palo Alto, CA, USA), was used. Helium was used as the carrier gas with a flow rate of $1 \mathrm{~mL} / \mathrm{min}$, and the oven temperature program was: $45-165{ }^{\circ} \mathrm{C}\left(4{ }^{\circ} \mathrm{C} / \mathrm{min}\right)$ and $165-280{ }^{\circ} \mathrm{C}\left(15^{\circ} \mathrm{C} / \mathrm{min}\right)$ with post run (off) at $280{ }^{\circ} \mathrm{C}$. Samples $(1 \mu \mathrm{L})$ were injected at $250{ }^{\circ} \mathrm{C}$, with split/splitless injector (50:1 split ratio) in the splitless mode flow with $10 \mathrm{~mL} / \mathrm{min}$. The GC-MS was equipped with a ZB-5MS Zebron capillary column (length $30 \mathrm{~m} \times 0.25 \mathrm{~mm}$ ID, $0.25 \mu \mathrm{m}$ film thickness; Agilent). Helium (average velocity $39 \mathrm{~cm} / \mathrm{s}$ ) was used as the carrier gas, and the oven temperature was held at $45^{\circ} \mathrm{C}$ for $2 \mathrm{~min}$, and then increased from 45 to $165{ }^{\circ} \mathrm{C}\left(4{ }^{\circ} \mathrm{C} / \mathrm{min}\right)$, and 165 to $280{ }^{\circ} \mathrm{C}\left(15{ }^{\circ} \mathrm{C} / \mathrm{min}\right)$.

All mass spectra were recorded in the electron impact ionization (EI) at 70 electron volts. The mass spectrometer was scanned from $\mathrm{m} / \mathrm{z} 50-500$ at five scans per second. Peak area percent was used for obtaining quantitative data with the GC with HP-ChemStation software (Agilent Technologies) without using correction factors. Identification of the constituents was performed based on MS library search (NIST and Wiley) [19-21]. Retention indices (RIs) were calculated using a generalized equation for all the components using a mixture of aliphatic hydrocarbons $\left(\mathrm{C}_{8}-\right.$ $\mathrm{C}_{32}$, Sigma-Aldrich) that was co-injected at the temperature program mentioned above equal to samples ones and computer matching with the Wiley 275.L and Wiley 7 n.L libraries. 


\section{$G C-M S$ analysis of the extracts}

Methanol, dichloromethane, and water extracts were analyzed for their chemical composition using Trace GC UltraISQ Mass Spectrometer (Thermo Scientific, Austin, TX, USA) with a direct capillary column TG-5MS $(30 \mathrm{~m} \times 0.25 \mathrm{~mm} \times 0.25 \mu \mathrm{m}$ film thickness $)$ apparatus at Atomic and Molecular Physics Unit, Experimental Nuclear Physics Department, Nuclear Research Centre, Egyptian Atomic Energy Authority, Inshas, Cairo, Egypt. The column oven temperature was initially held at $120{ }^{\circ} \mathrm{C}$ and then increased by $5{ }^{\circ} \mathrm{C} / \mathrm{min}$ to $200{ }^{\circ} \mathrm{C}$ with holding $2 \mathrm{~min}$ and then increased to $280{ }^{\circ} \mathrm{C}\left(10{ }^{\circ} \mathrm{C} / \mathrm{min}\right)$. Temperatures of the injector and detector (MS transfer line) were kept at $250{ }^{\circ} \mathrm{C}$. Helium, the carrier gas, was kept in constant flow rate of $1 \mathrm{~mL} / \mathrm{min}$. The solvent delay was $2 \mathrm{~min}$, and diluted samples of $1 \mu \mathrm{L}$ were injected automatically using Auto-sampler AS3000 coupled with GC in the split mode. EI mass spectra were collected at $70 \mathrm{eV}$ ionization voltages over the range of $m / z, 40-550$ in full-scan mode. The ion source and transfer line temperatures were set at 200 and $250{ }^{\circ} \mathrm{C}$, respectively. The components were identified by comparison of their retention times and mass spectra with those of WILEY 09 and NIST 11 mass spectral database [20].

\section{Determination of total phenolic and flavonoid contents}

The total phenolic (TP) and flavonoid contents (TF) were determined by Folin-Ciocalteau and aluminum chloride colorimetric methods, respectively [22]. For total phenolic contents, $1 \mathrm{~mL}$ of EOs, extracts, or standard solution of Tannic acid (10, 20, 40, 60, 80 and $100 \mathrm{mg} / \mathrm{L})$ was added to $25-\mathrm{mL}$ volumetric flask, containing $9 \mathrm{~mL}$ of distilled deionized water $\left(\mathrm{dd} \mathrm{H}_{2} \mathrm{O}\right.$ ). A reagent blank using dd $\mathrm{H}_{2} \mathrm{O}$ was prepared. $1 \mathrm{~mL}$ of Folin-Ciocalteu's phenol reagent was added to the mixture and shaken. After $5 \mathrm{~min}, 10 \mathrm{~mL}$ of $7 \% \mathrm{Na}_{2} \mathrm{CO}_{3}$ solution was added to the mixture. The solution was diluted to volume $(25 \mathrm{~mL})$ with $\mathrm{dd}_{2} \mathrm{O}$ and mixed. After incubation for $90 \mathrm{~min}$ at room temperature, the absorbance against prepared reagent blank was determined at $750 \mathrm{~nm}$ with an UV/Vis Spectrophotometer (Unico ${ }^{\circledR} 1200$, Alexandria, Egypt). The TP was expressed as milligrams of tannic acid equivalents (TAE) per $100 \mathrm{~g}$ extract (mg TAE/100 g dry extract).

For total flavonoid contents, an aliquot $(1 \mathrm{~mL})$ of EOs, extracts or standard solution of (+)-catechin $(10,20,40$, 60,80 and $100 \mathrm{mg} / \mathrm{L}$ ) was added to $10-\mathrm{mL}$ volumetric flask containing $4 \mathrm{~mL}$ of dd $\mathrm{H}_{2} \mathrm{O}$, and $0.3 \mathrm{~mL} 5 \% \mathrm{NaNO}_{2}$ was added to the flask. After $5 \mathrm{~min}, 0.3 \mathrm{~mL} 10 \% \mathrm{AlCl}_{3}$ was added. At 6th min, $2 \mathrm{~mL} 1 \mathrm{M} \mathrm{NaOH}$ was added, and the total volume was made up to $10 \mathrm{~mL}$ with dd $\mathrm{H}_{2} \mathrm{O}$. The solution was mixed well, and the absorbance was measured against prepared reagent blank at $510 \mathrm{~nm}$ (UV/Vis Spectrophotometer (Unico ${ }^{\circledR} 1200$, Alexandria, Egypt). TF was expressed as milligrams of (+)-catechin equivalents (CE) per gram extract (mg CE/g dry extract).

\section{Antioxidant activity of extracts}

The total antioxidant activity (TAA \%) of extracts and EOs was evaluated using the 2,2-diphenyl-1-picrylhydrazyl (DPPH) method [23]. Pure methanol (SigmaAldrich) was used to calibrate the spectrophotometer. An aliquot of $2 \mathrm{~mL}$ of stock solution of $0.1 \mathrm{mM} \mathrm{DPPH}$ (Sigma-Aldrich) reagent dissolved in pure methanol was added to a test tube containing $2 \mathrm{~mL}$ of the sample solution in methanol $(200 \mu \mathrm{g} / \mathrm{L})$. The mixture was mixed for approximately $10 \mathrm{~s}$ and left to stand in fibber box at room temperature in the dark for $30 \mathrm{~min}$. The absorbance was measured at $517 \mathrm{~nm}$, using a UV scanning spectrophotometer (Unico ${ }^{\circledR} 1200$ ).

TAA \% was expressed as the percentage inhibition of the DPPH radical using the following equation: TAA $(\%)=\left(A_{0}-A_{\mathrm{s}} / A_{0}\right) \times 100$, where TAA is the total antioxidant activity, $A_{0}$ (control) is the absorbance of DPPH solution in methanol and As is the absorbance of a DPPH solution with the tested sample (essential oils and extracts) or the positive controls (Tannic acid and (+)catechin) solutions. The control contained $2 \mathrm{~mL}$ of DPPH solution and $2 \mathrm{~mL}$ of methanol. The average values of TAA \% were carried out for three replicates, and are expressed as mean values \pm standard deviation (SD). Also, the antioxidant activity of each extract was expressed in terms of $\mathrm{IC}_{50}$ (the concentration required to inhibit DPPH radical formation by $50 \%$ ), calculated from the inhibition curve [24].

\section{Antibacterial activity of essential oils and extracts}

For preparation of the concentrated EOs, ME, DCME, and WE for the antibacterial assay, the respective amount of extracts were dissolved in $10 \%$ dimethyl sulfoxide (DMSO, Sigma-Aldrich, $10 \%$ DMSO was prepared by diluting the solvent in distilled water) to obtain the concentrations of $4,8,32,64,125,250,500,1000$, and $2000 \mu \mathrm{g} / \mathrm{mL}$ for each extract. We should mention that for the preparation of EOs concentration, $0.5 \mathrm{~mL}$ of Tween 80 was added to emulsify carrier oil in water.

Antibacterial activity of EOs and extracts from Schinus molle L. WB was assayed using the disk diffusion method [25], against the growth of the following human pathogenic bacteria: Bacillus subtilis, Bacillus cereus, Escherichia coli, Sarcina lutea, Staphylococcus aureus, Pseudomonas aeruginosa and Micrococcus luteus at the concentration of $200 \mu \mathrm{g} / \mathrm{mL}$. All the bacterial strains were provided by Prof. 
Yousry Gohar (Botany Department, Microbiology Section, Faculty of Science, Alexandria University, Egypt). Minimum inhibitory concentration (MICs) values were determined by serial dilution of the extracts and EOs (4, 8, 32, $64,125,250,500,1000$, and $2000 \mu \mathrm{g} / \mathrm{mL}$ ) in 96-well micro-plates [26]. Negative (DMSO) and positive (tetracycline $20 \mu \mathrm{g} / \mathrm{disk}$ ) controls were used, and all tests were performed in duplicate.

\section{Statistical analysis}

All the values of TP, TF, TAA $\%, \mathrm{IC}_{50}$, and the antibacterial activity are expressed as mean values $\pm \mathrm{SD}$. Analysis of variance (ANOVA) was used to evaluate the significant difference among various treatments with the criterion of $p \leq 0.05$.

\section{Results and discussion}

\section{GC/MS analysis of essential oils and extracts}

\section{Essential oils composition}

The identified thirty components representing $99.42 \%$ of the total essential oils (EOs) were presented in Table 1. The major chemical components of the EOs from Schinus molle L. wood branch (WB) were $\alpha$-elemol (14.79\%), $\beta$ pinene $(13.39 \%)$, myrcene $(12.26 \%), \alpha$-phellandrene $(10.41 \%)$, caryophyllene $(7.69 \%), \alpha$-cadinol $(5.18 \%)$, cadinene $(4.67 \%)$, elixene $(4.48 \%)$, nerolidol $(3.65 \%)$, $\beta$-eudesmol (4.01\%), $\gamma$-eudesmol (2.5\%), and germacrene-D-4-ol $(2.36 \%)$.

Generally, monoterpene hydrocarbons $(40.90 \%)$ and sesquiterpenes $(54.6 \%)$ were the main chemical groups in the EOs from WB of Schinus molle L., and small amount of sesquiterpenoids $(3.55 \%)$ and polycyclic aromatic hydrocarbon as tetrahydronaphthalenes $(0.37 \%)$ were found (Table 1).

Previously, there were many studies related to the EOs composition from different parts (leaves, berries and aerial parts) of Schinus molle L. from different regions of the world [8, 16, 27-30]. For example, studies with Italian leaf EOs [29, 30], and Tunisian leaf EOs [30, 31], referred that the main components may be different either in the same region or in percent of the component. Moreover, differences or similarities on chemical compositions suggest the presence of different chemotypes of Schinus molle L. $[15,17]$. The EOs composition of Schinus molle L. leaf grown in Italy contains $\alpha$ - and $\beta$-phellandrene and limonene [29], and the grown in southeast Portugal were reported to have $\alpha$-phellandrene, limonene, $\beta$-myrcene, $\beta$ phellandrene and elemol [32].
Table 1 Essential oil constituents of Schinus molle L. wood branch analyzed by gas chromatography-mass spectrometry (GC-MS)

\begin{tabular}{|c|c|c|}
\hline Constituent & $\mathrm{RI}^{\mathrm{a}}$ & Percentage in oil ${ }^{\mathrm{b}}$ \\
\hline$\alpha$-pinene & 939 & 1.6 \\
\hline Sabinene & 958 & 0.27 \\
\hline$\beta$-pinene & 979 & 13.39 \\
\hline Myrcene & 980 & 12.26 \\
\hline Ocimene & 993 & 0.26 \\
\hline$\alpha$-phellandrene & 1007 & 10.41 \\
\hline$\beta$-cymene & 1010 & 0.56 \\
\hline Linalool & 1100 & 1.7 \\
\hline Pinanediol & 1276 & 0.45 \\
\hline$(-)$ - $\beta$-elemene & 1364 & 1.72 \\
\hline$\alpha$-gurjunene & 1400 & 0.45 \\
\hline Caryophyllene & 1425 & 7.69 \\
\hline Elixene & 1430 & 4.48 \\
\hline Aromadendrene & 1439 & 0.24 \\
\hline Germacrene-D & 1444 & 0.48 \\
\hline$\gamma$-muurolene & 1460 & 0.72 \\
\hline$\gamma$-gurjunene & 1476 & 0.62 \\
\hline$\beta$-selinene & 1484 & 0.37 \\
\hline$\alpha$-muurolene & 1485 & 0.55 \\
\hline$\alpha$-elemol & 1523 & 14.79 \\
\hline Cadinene & 1529 & 4.67 \\
\hline Nerolidol & 1540 & 3.65 \\
\hline Trans-nerolidol & 1550 & 0.28 \\
\hline Palustrol & 1551 & 0.21 \\
\hline Germacrene-D-4-ol & 1557 & 2.36 \\
\hline$\gamma$-eudesmol & 1606 & 2.5 \\
\hline$\tau$-muurolol & 1626 & 1.75 \\
\hline Carotol & 1627 & 1.8 \\
\hline$\alpha$-cadinol & 1629 & 5.18 \\
\hline$\beta$-eudesmol & 1647 & 4.01 \\
\hline Monoterpene hydrocarbons & & $40.90 \%$ \\
\hline Sesquiterpenes & & $54.6 \%$ \\
\hline Sesquiterpenoids & & $3.55 \%$ \\
\hline PAHs & & $0.37 \%$ \\
\hline Total & & $99.42 \%$ \\
\hline Unidentified & & $0.58 \%$ \\
\hline
\end{tabular}

PAHs polycyclic aromatic hydrocarbons

${ }^{\text {a }}$ Identification of the essential oil components was performed by comparison of mass spectra and retention index (RI) obtained in both columns with those of reference compounds and those reported in the literature or with those of mass spectra libraries [20-22]

b Percentage of the total Flame Ionization Detector (FID) area obtained on Hewlett Packard (HP-5) capillary column

The major constituents of EOs from Schinus molle L. grown in Costa Rica were $\beta$-pinene and $\alpha$-pinene [33], while $p$-cymene $\alpha$-phellandrene, and sabinene were the major components in fruit and leaf EOs from Egypt $[34,35] . \alpha$-phellandrene, $\beta$-phellandrene, $\beta$-pinene, and 
$p$-cymene were found as major compounds in EOs extracted from berries of Schinus molle L. grown in Tunisia [3]. The main EOs compounds from the aerial parts were limonene, (E)-caryophyllene, bicyclogermacrene, germacrene, sabinene and spathulenol from Schinus molle L. grown in Southern Brazil [18]. $\alpha$-phellandrene was the main component of Schinus molle L. grown in Mexico [36].

The identified compounds in the EOs of WBs could be useful as a potential source in aromatherapy and pharmacy. The variation in the EOs compositions from aromatic and higher plants for the same species depends on several factors: genetic variability (chemotype); geographic location, ecologic factors, climatic conditions, the effect of intra-specific differences, soil-growth conditions, and extraction process [37]. The biological activities of the EOs are often attributed to their major compounds.

\section{GC-MS analysis of methanol extract}

Table 2 presents the chemical composition of ME of Schinus molle L. WB. The major components in ME were 6-(4-chlorophenyl)-3-cyano-4-( $N$-benzylpiperazino)-2H- pyran-2-one (26.00\%), 2-naphthalene methanol, decahydro- $\alpha, \alpha, 4$ a-trimethyl-8-methylene $(19.95 \%)$ and docosane (12.72\%), 3-(maleimido-2-yl)-1-methyl-2-(1-methylindol2-yl)indole $(6.37 \%)$, phenyl 4-[bis(ethoxy carbonyl)but-3-ynyl]-2,3,4-trideoxy- $\alpha$,L-glcero-pent-2enopyranoside $\quad(6.26 \%)$, 2H-Indeno[1,2-b]furan-2one,3,3a,4,5,6,7,8,8b-octahydro-8,8-dimethyl (6.16\%), hexadecanoic acid,1a,2,5,5a,6,9,10,10a-octahydro-5,5a-dihydroxy-4-(hydroxymethyl)-1,1,7,9-tetramethyl-11-oxo$1 \mathrm{H}-2,8 \mathrm{a}-\mathrm{methanocyclopenta[a]cyclopropa[e]cyclodecen-6-}$ yl ester $(5.95 \%)$, and lupanol (5.39\%).

\section{GC-MS analysis of dichloromethane extract}

The chemical composition of the identified 40 compounds of DCME of Schinus molle L. WB is presented in Table 3. The main components in DCME were 12-methyl-E,E-3,13octadecadien-1-ol (22.49\%), 1,2-benzenedicarboxylic acid, dioctyl ester (8.01\%), torreyol (6.46\%), acetic acid, (1,2,3,4,5,6,7,8-octahydro-3,8,8-trimethylnaphth-2-yl) methyl ester $(5.31 \%)$, elemol (4.71\%), trans-caryophyllene (3.94\%), (1-butylheptyl)-benzene (3.12\%), and (1pentylheptyl)-Benzene (3.09\%).

Table 2 The chemical compositions of methanol extract from Schinus molle L. branch wood analyzed by gas chromatography-mass spectrometry (GC-MS)

\begin{tabular}{|c|c|c|c|c|c|c|c|c|}
\hline $\begin{array}{l}\text { Peak } \\
\text { No. }\end{array}$ & RT & Compound name & $\begin{array}{l}\text { Molecular } \\
\text { formula }\end{array}$ & MW & $\begin{array}{l}\text { Peak } \\
\text { area } \\
\%\end{array}$ & SI & RSI & $\begin{array}{l}\text { Most fragment ions with RI } \\
(\%)\end{array}$ \\
\hline 1 & 3.63 & Docosane & $\mathrm{C}_{22} \mathrm{H}_{46}$ & 310 & 12.72 & 654 & 677 & $\begin{array}{l}43(88), 57(100), 71(34) \text { and } \\
99(10)\end{array}$ \\
\hline 2 & 14.99 & $\begin{array}{l}\text { 2H-Indeno[1,2-b]furan-2-one, } \\
\text { 3,3a,4,5,6,7,8,8b-octahydro-8,8-dimethyl }\end{array}$ & $\mathrm{C}_{13} \mathrm{H}_{18} \mathrm{O}_{2}$ & 206 & 6.16 & 423 & 517 & $\begin{array}{l}55(46), 81(47), 91(48), 191 \\
\quad(95), 206(3)\end{array}$ \\
\hline 3 & 22.23 & $\begin{array}{l}\text { 2-Naphthalene methanol,decahydro- } \\
\alpha, \alpha, 4 \mathrm{a} \text {-trimethyl-8-methylene }\end{array}$ & $\mathrm{C}_{15} \mathrm{H}_{26} \mathrm{O}$ & 222 & 19.95 & 495 & 659 & $\begin{array}{l}59(100), 81(35), 108(33), 164 \\
(40), 164(25) \text { and } 222(15)\end{array}$ \\
\hline 4 & 34.51 & $\begin{array}{l}\text { 3-(Maleimido-2-yl)-1-methyl-2- } \\
\text { (1-methylindol-2-yl)indole }\end{array}$ & $\mathrm{C}_{22} \mathrm{H}_{17} \mathrm{~N}_{3} \mathrm{O}_{2}$ & 355 & 6.37 & 368 & 688 & $\begin{array}{l}63(20), 127(25), 251(28), 269 \\
\quad(45), 164(25), 283(100) \text { and } \\
355(10)\end{array}$ \\
\hline 5 & 36.77 & $\begin{array}{l}\text { Androst-5-en-3-one, 19-acetoxy- } \\
\text { 4,4-dimethyl-,oxime }\end{array}$ & $\mathrm{C}_{23} \mathrm{H}_{35} \mathrm{NO}_{3}$ & 377 & 1.74 & 392 & 424 & $\begin{array}{l}95(43), 135(35), 283(45) \text { and } \\
\quad 300(100)\end{array}$ \\
\hline 6 & 37.34 & $\begin{array}{l}\text { 6-(4-Chlorophenyl)-3-cyano-4- } \\
\text { (N-benzylpiperazino)-2H-pyran-2-one }\end{array}$ & $\mathrm{C}_{23} \mathrm{H}_{20} \mathrm{ClN}_{3} \mathrm{O}_{2}$ & 405 & 26.00 & 419 & 791 & $\begin{array}{l}69(45), 109(25), 149(30), \text { and } \\
\quad 405(20)\end{array}$ \\
\hline 7 & 37.78 & Lupanol & $\mathrm{C}_{30} \mathrm{H}_{52} \mathrm{O}$ & 428 & 5.39 & 385 & 407 & $\begin{array}{l}91 \text { (100), } 218(25), \text { and } 428 \\
\text { (95) }\end{array}$ \\
\hline 8 & 38.31 & $\begin{array}{l}\text { Hexadecanoic acid,1a,2,5,5a,6,9,10,10a- } \\
\text { octahydro-5,5a-dihydroxy-4-(hydroxymethyl)- } \\
\text { 1,1,7,9-tetramethyl-11-oxo-1H-2,8a- } \\
\text { methanocyclopenta[a]cyclopropa[e]cyclodecen- } \\
\text { 6-yl ester }\end{array}$ & $\mathrm{C}_{36} \mathrm{H}_{58} \mathrm{O}_{6}$ & 586 & 5.95 & 427 & 431 & $\begin{array}{l}57(80), 266(100), 330(50), \\
\text { and } 551(3)\end{array}$ \\
\hline 9 & 40.24 & Lucenin 2 & $\mathrm{C}_{27} \mathrm{H}_{30} \mathrm{O}_{16}$ & 610 & 4.35 & 362 & 386 & $\begin{array}{l}156(25), 281(100), 322(25), \\
\text { and } 354(20)\end{array}$ \\
\hline 10 & 41.20 & $\begin{array}{l}\text { Phenyl 4-[bis(ethoxycarbonyl)but- 3-ynyl]-2,3,4- } \\
\text { trideoxy- } \alpha, \mathrm{L} \text {-glcero-pent-2-enopyranoside }\end{array}$ & $\mathrm{C}_{2} 1 \mathrm{H}_{26} \mathrm{O}_{6}$ & 374 & 6.26 & 481 & 968 & $281(85)$ and $374(3)$ \\
\hline
\end{tabular}

$R T$ retention time (min), $M W$ molecular wight $(\mathrm{g} / \mathrm{mol}), S I$ standard index, $R S I$ reverse standard index, $R I$ relative intensities 
Table 3 The chemical compositions of dichloromethane extract from Schinus molle L. branch wood analyzed by gas chromatography-mass spectrometry (GC-MS)

\begin{tabular}{|c|c|c|c|c|c|c|c|c|}
\hline $\begin{array}{l}\text { Peak } \\
\text { No. }\end{array}$ & RT & Compound name & $\begin{array}{l}\text { Molecular } \\
\text { formula }\end{array}$ & MW & $\begin{array}{l}\text { Peak } \\
\text { area } \%\end{array}$ & SI & RSI & Most fragment ions with RI (\%) \\
\hline 1 & 3.26 & Benzene, 1-ethyl-3-methyl & $\mathrm{C}_{9} \mathrm{H}_{12}$ & 120 & 0.33 & 856 & 938 & 105 (100) and $120(30)$ \\
\hline 2 & 3.54 & $\alpha$-Myrcene & $\mathrm{C}_{10} \mathrm{H}_{16}$ & 136 & 1.88 & 869 & 894 & $69(80), 93(85)$ and $136(15)$ \\
\hline 3 & 3.88 & 1-Phellandrene & $\mathrm{C}_{10} \mathrm{H}_{16}$ & 136 & 0.40 & 847 & 906 & 77 (45), 93 (100) and $136(25)$ \\
\hline 4 & 4.17 & Ethanone,1-(4-methylphenyl)- & $\mathrm{C}_{9} \mathrm{H}_{10} \mathrm{O}$ & 134 & 1.25 & 922 & 935 & $119(100)$ and $134(20)$ \\
\hline 5 & 4.26 & Limonene & $\mathrm{C}_{10} \mathrm{H}_{16}$ & 136 & 0.71 & 751 & 809 & $\begin{array}{l}68(100), 93(60), 121(25) \text { and } \\
136(25)\end{array}$ \\
\hline 6 & 4.30 & $\alpha$-Phellandrene & $\mathrm{C}_{10} \mathrm{H}_{16}$ & 136 & 0.61 & 720 & 789 & 77 (30), 93 (100) and 136 (20) \\
\hline 7 & 5.36 & $\begin{array}{l}\text { 1,4-Benzenedicarboxylic acid, 4- } \\
\text { (methoxycarbonyl)phenyl]methyl methyl } \\
\text { ester }\end{array}$ & $\mathrm{C}_{18} \mathrm{H}_{16} \mathrm{O}_{6}$ & 328 & 0.21 & 548 & 607 & 77 (30), 105 (40) and 133 (25) \\
\hline 8 & 10.65 & Exo-2-Hydroxy-5-ketobornane & $\mathrm{C}_{10} \mathrm{H}_{16} \mathrm{O}_{2}$ & 168 & 0.26 & 513 & 656 & 70 (45), 107 (40) and 168 (45) \\
\hline 9 & 11.17 & $\begin{array}{l}\text { 1-Methyl-4-(2-methyloxiranyl)-7- } \\
\text { oxabicyclo[4.1.0]heptane }\end{array}$ & $\mathrm{C}_{10} \mathrm{H}_{16} \mathrm{O}_{2}$ & 168 & 0.17 & 551 & 670 & 67(35), 93 (30) and 168 (10) \\
\hline 10 & 12.02 & (Z)-9-Octadecenoic acid & $\mathrm{C}_{18} \mathrm{H}_{34} \mathrm{O}_{2}$ & 282 & 0.20 & 512 & 544 & $55(100), 69(55)$ and $282(5)$ \\
\hline 11 & 12.24 & Phenylmethyl ester-hexadecanoic acid & $\mathrm{C}_{23} \mathrm{H}_{38} \mathrm{O}_{2}$ & 346 & 0.25 & 483 & 557 & $57(55), 91(100)$ and $108(80)$ \\
\hline 12 & 12.89 & $\begin{array}{l}\text { 2,4,5,6,7,8-Hexahydro-1,4, 9,9-tetramethyl- } \\
\text { 3H-3a,7-methanoazulene }\end{array}$ & $\mathrm{C}_{15} \mathrm{H}_{24}$ & 204 & 0.32 & 644 & 784 & 91 (80), 105 (85) and $204(90)$ \\
\hline 13 & 13.16 & trans-Caryophyllene & $\mathrm{C}_{15} \mathrm{H}_{24}$ & 204 & 3.94 & 792 & 810 & $\begin{array}{l}69 \text { (90), } 93 \text { (88), } 133 \text { (75) and } 204 \\
\text { (10) }\end{array}$ \\
\hline 14 & 13.98 & $\alpha$-Caryophyllene & $\mathrm{C}_{15} \mathrm{H}_{24}$ & 204 & 0.45 & 711 & 818 & $80(40), 93$ (100) and $204(15)$ \\
\hline 15 & 14.43 & $\begin{array}{l}\text { 1H-Benzocycloheptene, } 2,4 \mathrm{a}, 5,6,7,8,9,9 \mathrm{a}- \\
\text { octahydro-3,5,5-trimethyl-9-methylene-, } \\
\text { (4aS-cis) }\end{array}$ & $\mathrm{C}_{15} \mathrm{H}_{24}$ & 204 & 0.36 & 619 & 743 & $\begin{array}{l}93(80), 119(75), 189(60) \text { and } \\
204(25)\end{array}$ \\
\hline 16 & 14.98 & $\alpha$-Muurolene & $\mathrm{C}_{15} \mathrm{H}_{24}$ & 204 & 1.76 & 704 & 771 & $\begin{array}{l}93(45), 105(100), 161(40) \text { and } \\
204(20)\end{array}$ \\
\hline 17 & 15.36 & Seychellene & $\mathrm{C}_{15} \mathrm{H}_{24}$ & 204 & 0.85 & 681 & 790 & 91 (95), 105 (80) and 204 (50) \\
\hline 18 & 15.51 & $\alpha$-Copaene & $\mathrm{C}_{15} \mathrm{H}_{24}$ & 204 & 2.14 & 726 & 762 & $\begin{array}{l}93(45), 105(90), 119(95), 161 \\
\text { (100) and } 204(25)\end{array}$ \\
\hline 19 & 15.65 & (1-Butylhexyl)-benzene & $\mathrm{C}_{16} \mathrm{H}_{26}$ & 218 & 0.91 & 823 & 868 & $91(100), 147(20)$, and $218(10)$ \\
\hline 20 & 16.12 & Elemol & $\mathrm{C}_{15} \mathrm{H}_{26} \mathrm{O}$ & 222 & 4.71 & 768 & 772 & $\begin{array}{l}59(100), 93(80), 107(45) \text { and } \\
204(25)\end{array}$ \\
\hline 21 & 17.10 & Caryophyllene oxide & $\mathrm{C}_{15} \mathrm{H}_{24} \mathrm{O}$ & 220 & 2.22 & 760 & 797 & $\begin{array}{l}79 \text { (90), } 93 \text { (65), } 109 \text { (45) and } 220 \\
\text { (15) }\end{array}$ \\
\hline 22 & 17.29 & Epiglobulol & $\mathrm{C}_{15} \mathrm{H}_{26} \mathrm{O}$ & 222 & 0.48 & 655 & 707 & $\begin{array}{l}55(45), 82(60), 161(30) \text { and } 204 \\
\quad(30)\end{array}$ \\
\hline 23 & 17.56 & Palustrol & $\mathrm{C}_{15} \mathrm{H}_{26} \mathrm{O}$ & 222 & 0.23 & 589 & 831 & $\begin{array}{l}55(80), 69(60), 111(100) \text { and } \\
122(80)\end{array}$ \\
\hline 24 & 17.84 & (1-Methyldecyl)-benzene & $\mathrm{C}_{17} \mathrm{H}_{28}$ & 232 & 1.30 & 640 & 712 & $105(100)$, and $232(20)$ \\
\hline 25 & 17.91 & (1-Butylheptyl)-benzene & $\mathrm{C}_{16} \mathrm{H}_{26}$ & 232 & 3.12 & 775 & 802 & $91(100), 147(20)$, and $232(20)$ \\
\hline 26 & 18.14 & $\begin{array}{l}\text { Acetic acid, (1,2,3,4,5,6,7,8-octahydro- } \\
\text { 3,8,8-trimethylnaphth-2-yl) methyl ester }\end{array}$ & $\mathrm{C}_{16} \mathrm{H}_{26} \mathrm{O}_{2}$ & 250 & 5.31 & 571 & 580 & $\begin{array}{l}105(60), 175(80), 190(45) \text { and } \\
250(30)\end{array}$ \\
\hline 27 & 18.31 & Junipene & $\mathrm{C}_{15} \mathrm{H}_{24}$ & 204 & 2.57 & 676 & 703 & $91(60), 105(45)$, and $204(30)$ \\
\hline 28 & 18.62 & 12-Methyl-E,E-3,13-octadecadien-1-ol & $\mathrm{C}_{19} \mathrm{H}_{36} \mathrm{O}$ & 280 & 22.49 & 609 & 623 & $55(100), 121(40)$, and $248(20)$ \\
\hline 29 & 19.46 & $\begin{array}{l}\text { 5-Ethyl-5-hydroxy-3-methyl-2- } \\
\text { phenyltetrahydrofuran-2-carboxylic acid }\end{array}$ & $\mathrm{C}_{14} \mathrm{H}_{18} \mathrm{O}_{4}$ & 250 & 2.64 & 866 & 995 & $105(100)$ \\
\hline 30 & 20.00 & (1-pentylheptyl)-Benzene & $\mathrm{C}_{18} \mathrm{H}_{30}$ & 246 & 3.09 & 667 & 686 & $91(100)$, and $246(15)$ \\
\hline 31 & 20.11 & (1-butyloctyl)-Benzene & $\mathrm{C}_{18} \mathrm{H}_{30}$ & 246 & 2.94 & 842 & 843 & $91(100), 147$ (20), and $246(10)$ \\
\hline 32 & 20.38 & (1-propylnonyl)-Benzene & $\mathrm{C}_{18} \mathrm{H}_{30}$ & 246 & 2.07 & 745 & 755 & $91(100), 133(35)$, and $246(10)$ \\
\hline
\end{tabular}


Table 3 continued

\begin{tabular}{lllllllll}
\hline $\begin{array}{l}\text { Peak } \\
\text { No. }\end{array}$ & RT & Compound name & $\begin{array}{l}\text { Molecular } \\
\text { formula }\end{array}$ & MW & $\begin{array}{l}\text { Peak } \\
\text { area } \%\end{array}$ & SI & RSI & Most fragment ions with RI (\%) \\
\hline 33 & $20.48 \begin{array}{l}\text { 1-Cyclohexanone, 2-methyl-2-(3-methyl-2- } \\
\text { oxobutyl) }\end{array}$ & $\mathrm{C}_{12} \mathrm{H}_{20} \mathrm{O}_{2}$ & 196 & 0.22 & 508 & 687 & $153(100)$ and 196 (10) \\
34 & 21.11 & Calarene epoxide & $\mathrm{C}_{15} \mathrm{H}_{24} \mathrm{O}$ & 220 & 0.22 & 564 & 706 & $69(60), 93(45)$, and 220 (25) \\
35 & 21.29 & Isoaromadendrene epoxide & $\mathrm{C}_{15} \mathrm{H}_{24} \mathrm{O}$ & 220 & 1.31 & 673 & 739 & $55(60), 107(45)$, and 220 (20) \\
36 & 21.72 & 2-Benzyl-3-heptyloxirane & $\mathrm{C}_{16} \mathrm{H}_{22} \mathrm{O}_{2}$ & 246 & 1.46 & 877 & 965 & $105(100)$ \\
37 & 22.21 & Torreyol & $\mathrm{C}_{15} \mathrm{H}_{26} \mathrm{O}$ & 222 & 6.46 & 617 & 643 & $119(40), 161(100), 204(20)$ and \\
38 & 23.22 & 11-phenyl-Heneicosane & $\mathrm{C}_{27} \mathrm{H}_{48}$ & 372 & 0.86 & 549 & 608 & $91(100), 231(30)$, and 372 (10) \\
39 & 23.31 & 17-Pentatriacontene & $\mathrm{C}_{35} \mathrm{H}_{70}$ & 490 & 0.72 & 581 & 622 & $57(90), 83(55)$, and 490 (5) \\
40 & 37.32 & 1,2-Benzenedicarboxylic acid, dioctyl ester & $\mathrm{C}_{24} \mathrm{H}_{38} \mathrm{O}_{4}$ & 390 & 8.01 & 566 & 661 & $57(70), 149(100)$, and 390 (5) \\
\hline
\end{tabular}

$R T$ retention time (min), $M W$ molecular wight $(\mathrm{g} / \mathrm{mol}), S I$ standard index, $R S I$ reverse standard index, $R I$ relative intensities

\section{GC-MS analysis of water extract}

The identified chemical composition of WE from Schinus molle $\mathrm{L}$. WB is shown in Table 4 and represented 37 compounds. The main chemical compounds in WE were $\beta$ eudesmol (39.4\%), and (Z,Z,Z)-9,12,15-octadecatrienoic acid, 2,3-dihydroxypropyl ester (3.20\%).

In accordance with the previous findings, most of the identified compounds have been reported elsewhere in other studies on the same species and/or other species such as limonene, $\alpha$-phellandrene, myrcene, elemol and caryophyllene in DCME of Schinus molle L. WB and these compounds were reported in the ME of leaves and fruits of Schinus molle L. [38]. 2-Naphthalene methanol, decahydro- $\alpha, \alpha, 4 a$-trimethyl- 8 -methylene was identified as the major compound of hydro-distillation and methanol extracts of Schinus molle L. WB and was reported as a major compound in the hydro-distillation extract of the aerial parts of Ferula assafoetida. 12-methyl-E,E-3,13octadecadien-1-ol was identified as the major (22.49\%) compound of DCME of Schinus molle L. WB as well as a major compound in the ethanolic seed extract of Syzygium cumini [39]. Docosane was presented as a major compound in steam distillation extract of the aerial part, flowers, leaves and stems of Tamarix boveana [40].

Some of the identified compounds have been reported to possess various biological activities. For instance, antioxidant, antimicrobial, anti-inflammatory, anticancer, antialdosteronic, antihepatotoxic, antinociceptive, antiophidic, antiencephalopathic, antigastritic, antiprostatitic, antipruritic and hypocholesterolemic activities as summarized in Table 5. Among the identified phytochemicals, hexadecanoic acid, phenylmethyl ester (palmitic acid ester) is reported to be an antioxidant, hypocholesterolemic, antiandrogenic, hemolytic [41], while 6,9,12-octadecatrienoic acid, methyl ester is said to be a cancer-preventive, anti-inflammatory, hypocholesterole, and hepatoprotective [41]. Other antioxidants presented were stigmast-5-en-3-ol and myrcene. The presence of antioxidants in Schinus molle L. WB extracts justifies the observed antioxidant property $[10,14,42]$.

\section{Total phenolic, flavonoid contents and antioxidant activity}

The contents of total phenolic (TP) equivalent to tannic acid (TA) and total flavonoid (TF) equivalent to (+)-catechin (CA) of ME, DCME, and WE from Schinus molle L. WB are presented in Table 6. In addition, the total antioxidant activity (TAA \%) for ME, DCME, and WE, as well as the EOs was reported. The highest values of TP content $(30.90 \pm 1.90 \mathrm{mg} \mathrm{TAE} / \mathrm{g}$ extract $)$ was found in WE, and the highest TF content $(50.70 \pm 1.80 \mathrm{mg} \mathrm{CAE} / \mathrm{g}$ extract) reported with $\mathrm{ME}(50.70 \pm 1.80 \mathrm{mg} \mathrm{CAE} / \mathrm{g}$ extract). The TAA \% found with EOs $(90 \pm 1.23 \%)$ was followed by WE $(86.30 \pm 1.40 \%)$, and these values were higher than those measured by TA and CA $(85 \pm 5.12$, and $84.13 \pm 1.90$, respectively). Also, the lowest $\mathrm{IC}_{50}$ was found by WE and EOs with values of $13.11 \pm 3.00$, and $12.66 \pm 2.15 \mu \mathrm{g} / \mathrm{mL}$, respectively, and those values were lower than the $\mathrm{IC}_{50}$ of $\mathrm{TA}$ and $\mathrm{CA}(24.70 \pm 0.48$, and $30.75 \pm 0.88 \mu \mathrm{g} / \mathrm{mL}$, respectively).

Pharmacologically, the extracts of leaves from Schinus molle L. had antioxidant and anticancer activities [43]. The concentration values $>250 \mu \mathrm{g} / \mathrm{mL}$ of the EOs had a good antioxidant activity [36]. EOs with a concentration of $16 \mathrm{mg} / \mathrm{mL}$ was promoted a free radical scavenging effect of $4.8 \%$; however, this is much lower than that which was observed for ascorbic acid as a standard one [32].

Previously, TAA \% of leaves EOs was weak [33]. Also, EOs with ability to scavenge the DPPH radical are of main interest in food industry as the antioxidant capacity is 
Table 4 The chemical compositions of water extract from Schinus molle L. wood branch analyzed by gas chromatography-mass spectrometry (GC-MS)

\begin{tabular}{|c|c|c|c|c|c|c|c|c|}
\hline $\begin{array}{l}\text { Peak } \\
\text { No. }\end{array}$ & RT & Compound name & $\begin{array}{l}\text { Molecular } \\
\text { formula }\end{array}$ & MW & $\begin{array}{l}\text { Peak } \\
\text { area } \%\end{array}$ & SI & RSI & Most fragment ions with RI (\%) \\
\hline 1 & 2.60 & 8-Octadecenal & $\mathrm{C}_{18} \mathrm{H}_{34} \mathrm{O}$ & 266 & 0.84 & 484 & 523 & 57 (100), 83 (80), and $97(45)$ \\
\hline 2 & 2.77 & 2-(1-Phenanthryl)benzaldehyde & $\mathrm{C}_{21} \mathrm{H}_{14} \mathrm{O}$ & 282 & 0.64 & 448 & 726 & $252(60)$ and $282(96)$ \\
\hline 3 & 2.86 & Decane & $\mathrm{C}_{10} \mathrm{H}_{22}$ & 142 & 2.22 & 688 & 869 & 57 (100), $71(50)$, and $142(20)$ \\
\hline 4 & 3.49 & Docosane & $\mathrm{C}_{22} \mathrm{H}_{46}$ & 310 & 0.63 & 427 & 442 & 57 (95), $71(60)$, and $310(5)$ \\
\hline 5 & 4.69 & Deoxyspergualin & $\mathrm{C}_{17} \mathrm{H}_{37} \mathrm{~N}_{7} \mathrm{O}_{3}$ & 387 & 0.32 & 430 & 482 & 72 (60), 86 (35), and 387 (2) \\
\hline 6 & 4.92 & $\begin{array}{l}\text { 2,3-Dihydro-3,5-dihydroxy-6-methyl-4H- } \\
\text { pyran-4-one }\end{array}$ & $\mathrm{C}_{6} \mathrm{H}_{8} \mathrm{O}_{4}$ & 144 & 2.16 & 545 & 858 & $\begin{array}{l}55(100), 101(40) \text {, and } 144 \\
\quad(45)\end{array}$ \\
\hline 7 & 5.42 & $\begin{array}{l}\text { N2-(3-indolylmethylene)-furan-2- } \\
\text { carbohydrazide }\end{array}$ & $\mathrm{C}_{14} \mathrm{H}_{11} \mathrm{~N}_{3} \mathrm{O}_{2}$ & 253 & 0.44 & 395 & 504 & $\begin{array}{l}95(90), 142(100) \text {, and } 253 \\
\quad(25)\end{array}$ \\
\hline 8 & 6.53 & Prednisone & $\mathrm{C}_{21} \mathrm{H}_{26} \mathrm{O}_{5}$ & 358 & 0.74 & 399 & 451 & $\begin{array}{l}121(100), 147(65), 299(45) \\
\text { and } 358(35)\end{array}$ \\
\hline 9 & 8.20 & $\begin{array}{l}\text { 6-(3-Hydroxy-but-1-enyl)-1,5,5-trimethyl-7- } \\
\text { oxabicyclo [4.1.0]heptan-2-ol }\end{array}$ & $\mathrm{C}_{13} \mathrm{H}_{22} \mathrm{O}_{3}$ & 226 & 1.55 & 523 & 615 & $\begin{array}{l}55(35), 100(40), 125(45) \text { and } \\
226(5)\end{array}$ \\
\hline 10 & 9.80 & $\begin{array}{l}\text { 3,6-Epoxy-2H,8H-pyrimido[6,1-b][1, } \\
\text { 3]oxazocin-8-one, 3,4,5,6-tetrahydro-4- } \\
\text { hydroxy-10-amino }\end{array}$ & $\mathrm{C}_{9} \mathrm{H}_{11} \mathrm{~N}_{3} \mathrm{O}_{4}$ & 225 & 1.48 & 511 & 617 & $\begin{array}{l}81(75), 111(90), 152(45) \text { and } \\
225(25)\end{array}$ \\
\hline 11 & 10.73 & $\alpha$-Cedrene & $\mathrm{C}_{15} \mathrm{H}_{24}$ & 204 & 1.06 & 464 & 569 & $69(80), 119(100)$ and $204(45)$ \\
\hline 12 & 11.86 & $\begin{array}{l}\text { 18,21-Didehydro-6,17-didemethoxy-18,21- } \\
\text { dideoxo-18,21-dihydroxy-15-methoxy-6- } \\
\text { methyl-11-O-methyl-geldanamycin }\end{array}$ & $\mathrm{C}_{30} \mathrm{H}_{44} \mathrm{~N}_{2} \mathrm{O}_{8}$ & 560 & 0.61 & 425 & 482 & $\begin{array}{l}79(90), 122(92) 288(25) \text { and } \\
560(1)\end{array}$ \\
\hline 13 & 15.44 & $\begin{array}{l}\text { 2-(7-Hydroxymethyl-3,11-dimethyl-dodeca- } \\
\text { 2,6,10-trienyl)-[1,4]benzoquinone }\end{array}$ & $\mathrm{C}_{21} \mathrm{H}_{28} \mathrm{O}_{3}$ & 328 & 0.89 & 469 & 521 & $\begin{array}{l}69(100), 123(25), 161(55) \\
\text { and } 328(5)\end{array}$ \\
\hline 14 & 15.92 & $6,9,12$-Octadecatrienoic acid, methyl ester & $\mathrm{C}_{19} \mathrm{H}_{32} \mathrm{O}_{2}$ & 292 & 5.96 & 485 & 521 & $\begin{array}{l}55(50), 67(55), 79(45) \text { and } \\
292(20)\end{array}$ \\
\hline 15 & 16.40 & $\begin{array}{l}\text { 1-Propyl-2-methyl-7-methoxy-5H,6H- } \\
\text { pyrido[3,4-b]indole }\end{array}$ & $\mathrm{C}_{16} \mathrm{H}_{20} \mathrm{~N}_{2} \mathrm{O}$ & 256 & 0.36 & 441 & 497 & 83 (100), $213(60)$ and $256(15)$ \\
\hline 16 & 17.78 & $\begin{array}{l}\text { (1,5,5,8-Tetramethyl-bicyclo[4.2.1]non-9- } \\
\text { yl)-acetic acid }\end{array}$ & $\mathrm{C}_{15} \mathrm{H}_{26} \mathrm{O}_{2}$ & 238 & 1.19 & 450 & 503 & $95(65), 153(100)$ and $238(15)$ \\
\hline 17 & 19.48 & $\beta$-Eudesmol & $\mathrm{C}_{15} \mathrm{H}_{26} \mathrm{O}$ & 222 & 39.4 & 693 & 805 & $\begin{array}{l}59(100), 149(45), 204(20) \\
\text { and } 222(25)\end{array}$ \\
\hline 18 & 19.61 & $\begin{array}{l}\text { Acetic acid, 17-(1-acetoxy-ethyl)-10,13 - } \\
\text { dimethyl-3-oxo- } \\
\text { 2,3,8,9,10,11,12,13,14,15,16,17- } \\
\text { dodecahydro-1H- } \\
\text { cyclopenta[a] phenanthren-11-yl }\end{array}$ & $\mathrm{C}_{25} \mathrm{H}_{34} \mathrm{O}_{5}$ & 414 & 0.23 & 429 & 453 & $\begin{array}{l}159(25), 279(30), 294(40) \\
\text { and } 414(5)\end{array}$ \\
\hline 19 & 19.70 & Murolan-3,9(11)-diene-10-peroxy & $\mathrm{C}_{15} \mathrm{H}_{24} \mathrm{O}_{2}$ & 236 & 1.16 & 471 & 605 & $\begin{array}{l}69(60), 91(65), 159(75) \text { and } \\
236(15)\end{array}$ \\
\hline 20 & 20.24 & Ethyl iso-allocholate & $\mathrm{C}_{26} \mathrm{H}_{44} \mathrm{O}_{5}$ & 436 & 1.52 & 492 & 515 & $\begin{array}{l}55(95), 69(75), 107(45) \text { and } \\
436(2)\end{array}$ \\
\hline 21 & 20.39 & Carotene & $\mathrm{C}_{40} \mathrm{H}_{56}$ & 536 & 0.50 & 520 & 521 & $\begin{array}{l}119(45), 159(75), \text { and } 536 \\
(10)\end{array}$ \\
\hline 22 & 20.51 & 24,25-Dihydroxycholecalciferol & $\mathrm{C}_{27} \mathrm{H}_{44} \mathrm{O}_{3}$ & 416 & 1.30 & 494 & 550 & $\begin{array}{l}55(100), 118(90), 136(100) \\
\text { and } 416(2)\end{array}$ \\
\hline 23 & 20.79 & $\begin{array}{l}\text { 12,12a-Dihydroxy-2,2,7,7,9,11-hexamethyl- } \\
\text { 7H-6,9a-methano-4H- } \\
\text { cyclopenta[9,10]cyclopropa[5,6] } \\
\text { cyclodeca[1,2-d]-1,3-dioxin-13- } \\
\text { one,6,6a,7a,8,9,12,12a,12b-oct ahydro }\end{array}$ & $\mathrm{C}_{23} \mathrm{H}_{32} \mathrm{O}_{5}$ & 388 & 2.94 & 504 & 537 & $\begin{array}{l}91(90), 121(100), 284(65) \\
\text { and } 388(15)\end{array}$ \\
\hline 24 & 21.74 & $\begin{array}{l}\text { (Z,Z,Z)-9,12,15-Octadecatrienoic acid, 2,3- } \\
\text { dihydroxypropyl ester }\end{array}$ & $\mathrm{C}_{21} \mathrm{H}_{36} \mathrm{O}_{4}$ & 352 & 3.20 & 530 & 574 & $\begin{array}{l}79(100), 95(65), 15(35) \text { and } \\
352(5)\end{array}$ \\
\hline
\end{tabular}


Table 4 continued

\begin{tabular}{|c|c|c|c|c|c|c|c|c|}
\hline $\begin{array}{l}\text { Peak } \\
\text { No. }\end{array}$ & RT & Compound name & $\begin{array}{l}\text { Molecular } \\
\text { formula }\end{array}$ & MW & $\begin{array}{l}\text { Peak } \\
\text { area } \%\end{array}$ & SI & RSI & Most fragment ions with RI (\%) \\
\hline 25 & 22.14 & Stigmast-5-en-3-ol & $\mathrm{C}_{29} \mathrm{H}_{50} \mathrm{O}$ & 414 & 0.94 & 505 & 521 & $\begin{array}{l}91(100), 145(65), 255(35) \\
\quad \text { and } 414(2)\end{array}$ \\
\hline 26 & 22.23 & 1,5-Diphenyl-1,4-pentadien-3-one & $\mathrm{C}_{24} \mathrm{H}_{34} \mathrm{O}_{3}$ & 370 & 0.80 & 439 & 494 & $55(40), 161(30)$ and $370(45)$ \\
\hline 27 & 22.50 & Cassamic acid methyl ester & $\mathrm{C}_{22} \mathrm{H}_{32} \mathrm{O}_{5}$ & 376 & 0.29 & 409 & 431 & $268(45), 327(90)$ and $376(1)$ \\
\hline 28 & 22.61 & Sophoracarpan B & $\mathrm{C}_{17} \mathrm{H}_{14} \mathrm{O}_{6}$ & 314 & 0.68 & 440 & 698 & $282(100)$ and $314(30)$ \\
\hline 29 & 22.86 & $\begin{array}{l}\text { 14-Hydroxy-13-methoxycodeinone- } \\
\text { hydrazone }\end{array}$ & $\mathrm{C}_{18} \mathrm{H}_{21} \mathrm{~N}_{3} \mathrm{O}_{3}$ & 327 & 1.48 & 405 & 745 & $\begin{array}{l}281(80), 309(40), 152(96) \\
\text { and } 327(96)\end{array}$ \\
\hline 30 & 23.21 & $\begin{array}{l}\text { 9-Desoxo-9-x-acetoxy-3,8,12-tri-O- } \\
\text { acetylingol }\end{array}$ & $\mathrm{C}_{28} \mathrm{H}_{40} \mathrm{O}_{10}$ & 536 & 2.07 & 497 & 512 & $69(25), 122(300)$ and $536(5)$ \\
\hline 31 & 23.63 & $\begin{array}{l}\text { Dodecanoic acid, 1a,2,5,5a,6,9,10,10a- } \\
\text { octahydro-5,5a-dihydroxy-4- } \\
\text { (hydroxymethyl)-1,1,7,9-tetra methyl-11- } \\
\text { oxo-1H-2,8a-methanocyclopenta[a]cyclopr } \\
\text { opa[e]cyclodecen-6-yl ester }\end{array}$ & $\mathrm{C}_{32} \mathrm{H}_{50} \mathrm{O}_{6}$ & 530 & 0.70 & 417 & 421 & $122(100), 312(40)$ and $530(2)$ \\
\hline 32 & 24.75 & Olean-12-ene-3,15,16,21, 22,28-hexol & $\mathrm{C}_{30} \mathrm{H}_{50} \mathrm{O}_{6}$ & 506 & 0.33 & 388 & 407 & $\begin{array}{l}249(100), 280(75), 334(45) \\
\quad \text { and } 506(2)\end{array}$ \\
\hline 33 & 26.38 & Stearic acid, 3-(octadecyloxy)propylester & $\mathrm{C}_{39} \mathrm{H}_{78} \mathrm{O}_{3}$ & 594 & 1.78 & 443 & 461 & $\begin{array}{l}71(100), 281(70), 325(60) \\
\text { and } 594(5)\end{array}$ \\
\hline 34 & 27.27 & $\begin{array}{l}\text { 2-(3-Acetoxy-4,4,14-trimethylandrost-8-en- } \\
\text { 17-yl)-propanoic acid }\end{array}$ & $\mathrm{C}_{27} \mathrm{H}_{42} \mathrm{O}_{4}$ & 430 & 0.60 & 426 & 438 & $\begin{array}{l}83(45), 355(100), 415(45) \\
\quad \text { and } 430(25)\end{array}$ \\
\hline 35 & 31.09 & Colchiceine & $\mathrm{C}_{21} \mathrm{H}_{23} \mathrm{NO}_{6}$ & 385 & 2.51 & 382 & 418 & $115(40), 314(60)$ and $385(85)$ \\
\hline 36 & 32.88 & Deoxyherqueinone & $\mathrm{C}_{20} \mathrm{H}_{20} \mathrm{O}_{6}$ & 356 & 0.43 & 385 & 769 & $341(100)$, and $356(80)$ \\
\hline 37 & 32.95 & $\begin{array}{l}\text { 1H-Pyrrole-3,4-diacetic acid, } \\
\text { 2-acetoxymethyl-5-methoxycarbonyl-, } \\
\text { dimethyl ester }\end{array}$ & $\mathrm{C}_{15} \mathrm{H}_{19} \mathrm{NO}_{8}$ & 341 & 0.89 & 360 & 429 & $\begin{array}{l}190(65), 281(100) \text { and } 341 \\
(25)\end{array}$ \\
\hline
\end{tabular}

$R T$ retention time $(\mathrm{min}), M W$ molecular wight $(\mathrm{g} / \mathrm{mol}), S I$ standard index, $R S I$ reverse standard index, $R I$ relative intensities

nowadays accepted as a criterion of high food quality [44]. On the other hand, oil of berries had a good antioxidant activity $[2,30]$. Myrcene represented a percentage of the total $12.26 \%$ in the oil of the WBs, and it was reported that the EOs of the chemotype rosemary rich in myrcene had the highest antioxidant activity and probably due to the high content of myrcene [44]. ME of Schinus molle L. bark and flowers exhibited remarkable antioxidant activity with $\mathrm{EC}_{50}$ values of $8.6 \pm 1.6$ and $15.2 \pm 4.0 \mu \mathrm{g} / \mathrm{mL}$, respectively [7].

\section{Antibacterial activity}

Table 7 presents that the highest inhibition zone (IZ, mm) against the growth of B. subtilis, B. cereus, E. coli, S. lutea, $P$. aeruginosa, and $M$. luteus was observed by WE of Schinus molle L. WB with values of $18 \pm 1.12,20 \pm 3.14$, $15 \pm 0.33, \quad 15 \pm 2.12, \quad 16 \pm 1.13, \quad 14 \pm 0.33 \mathrm{~mm}$, respectively. On the other hand, EOs and ME showed the highest IZ values against the growth of $S$. aureus with values of $15 \pm 0.33$ and $15 \pm 1.33 \mathrm{~mm}$, respectively. Furthermore, most of IZ values are lower than those values obtained from the standard antibiotic.
According to the MIC values presented in Table 7, the EOs observed good antibacterial activity against the studied bacterial strains with MIC values of $250,32,64,125$, 125,250 , and $500 \mu \mathrm{g} / \mathrm{mL}$, against the growth of B. subtilis, B. cereus, S. aureus, E. coli, S. lutea, P. aeruginosa, and M. luteus, respectively. However, these MIC values were lower than the value of positive control used (Tetracycline, $20 \mu \mathrm{g} /$ disk) (Table 7).

The MIC values ranged from 32 to $1000 \mu \mathrm{g} / \mathrm{mL}$ for the $\mathrm{ME}$ and between 125 and $1000 \mu \mathrm{g} / \mathrm{mL}$ with DCME, and these values were higher than those from conventional antibiotic used (Tetracycline, $20 \mu \mathrm{g} / \mathrm{disk}$ ) (Table 7). On the other hand, WE showed good antibacterial activity, where the MIC value for $B$. subtilis was $4 \mathrm{mg} / \mathrm{mL}, B$. cereus $32 \mathrm{mg} / \mathrm{mL}$, S. aureus $8 \mathrm{mg} / \mathrm{mL}$, E. coli $8 \mathrm{mg} / \mathrm{mL}$, S. lutea $4 \mathrm{mg} / \mathrm{mL}, P$. aeruginosa $32 \mathrm{mg} / \mathrm{mL}$ and for M. luteus $125 \mathrm{mg} / \mathrm{mL}$ (Table 7). Clearly, the MIC values showed that the EOs and WE owned good antibacterial activity than either ME or DCME.

Previously, the EOs extracted from the fresh leaves of Schinus molle L. showed a significant activity against Klebsiella pneumoniae, Alcaligenes faecalis, P. aeruginosa, Leuconostoc cremoris, Enterobacter aerogenes, 
Table 5 Summary of chemical compounds identified from the Schinus molle L. wood branch extracts and their general biological activities (Modified from Dr. Duke's: Phytochemical and Ethnobotanical Databases)

\begin{tabular}{lc}
\hline Chemical compounds & Biological activities \\
\hline 1- Stigmast-5-en-3-ol & $\begin{array}{c}\text { Antihepatotoxic, anti-inflammatory, antinociceptive, antiophidic, } \\
\text { antioxidant; antiviral, artemicide, cancer-preventive, estrogenic, } \\
\text { hypocholesterolemic, ovulant; sedative }\end{array}$ \\
$\begin{array}{l}\text { 5-alpha-reductase-inhibitor, cosmetic, flavor, hypocholesterolemic; } \\
\text { lubricant, perfumery; propecic, suppository }\end{array}$ \\
3- Stearic acid, 3-(octadecyloxy)propylester & Flavor
\end{tabular}

ydro-5,5a-dihydroxy-4-(hydroxymethyl)-1,1,7,9-tetra

Flavor

methyl-11-oxo-1H-2,8a-methanocyclopenta[a]cyclopr

opa[e]cyclodecen-6-yl ester

5- (Z,Z,Z)-9,12,15-octadecatrienoic acid -2,3- dihydroxypropyl ester

6- Acetic acid, 17-(1-acetoxy-ethyl)-10,13 -dimethyl-3-oxo-

2,3,8,9,10,11,12,13,14,15,16,17-dodecahydro-1H-

cyclopenta[a] phenanthren-11-yl

7- 2-Naphthalene methanol, decahydro- $\alpha, \alpha, 4$ a-trimethyl-8-methylene

8- 6,9,12-Octadecatrienoic acid, methyl ester

2,3-Dihydro-3,5-dihydroxy-6-methyl-4H-pyran-4-one

10- 2-(1-Phenanthryl)benzaldehyde

\section{1- (1-Butylheptyl)-benzene}

12- 1,2-Benzenedicarboxylic acid, diisooctyl ester

13- Torreyol

14- Benzene, (1-pentylheptyl)

15- Caryophyllene oxide

16- Hexadecanoic acid, phenylmethyl ester

17- (1-Propylnonyl)-benzene

18- (Z)-9-Octadecenoic acid

19- $\alpha$-Phellandrene

20- (1-methyldecyl)-benzene

21- Limonene

22- Myrcene

23- (1-Butyloctyl)-benzene
Analgesic, antipyretic, anticonvulsant, antiseptic

Acidulant, antibacterial, antiotitic, antisalmonella, antivaginitic, expectorant, fungicide, keratitigenic, mucolytic, osteolytic, perfumery, pesticide, protisticide, spermicide, ulcerogenic, verrucolytic

\section{Cataractagenic}

Anti-inflammatory, hypocholesterolemic, cancer-preventive, hepatoprotective, nematicide, insectifuge antihistaminic, antiarthritic, anticoronary, antieczemic, antiacne, $5-\alpha$ reductase inhibitor antiandrogenic

Antimicrobial, anti-inflammatory

Allergenic, anesthetic, antibacterial, anticancer, antimutagenic, antipeptic, antiseptic, antisp, nematicide, insecticide, pesticide

Antimicrobial

Antimicrobial antifouling

Pesticide, termiticide

Antimicrobial

Antiedemic, antifeedant, anti-inflammatory, antitumor, calciumantagonist, fungicide, insecticide, pesticide

Antioxidant, hypocholesterolemic, antiandrogenic, hemolyti

Antimicrobial

Cancer-preventive, insectifuge

Hyperthermic, Irritant, Spasmogenic, Tumor-Promoter;

Antimicrobial

AChE-inhibitor, acaricide, allelochemic, allergenic, antiacetylcholinesterase, antiadenomic, antialzheimeran, antiasthmatic, antibacterial; anticancer, antiesophagitic, antifeedant, antiflu, anti-inflammatory, antilithic, antilymphomic, antimetastatic (stomach), antimutagenic, antiobesity, antiseptic, antispasmodic, antitumor, antitumor (breast), antitumor (colon), antitumor (pancreas), antitumor (prostate), antitumor (stomach), antiviral, apoptotic, bronchoprotectant, cancer-preventive, candidistat, chemopreventive, cholesterolytic, detoxicant, enterocontractant, expectorant, flavor, fungiphilic, fungistat, GST-inducer, herbicide, histaminic, immunomodulator, insecticide, insectifuge, interleukin-6-inhibitor, irritant, lipolytic, myorelaxant, nematicide, ornithine-decarboxylaseinhibitor, ozone-scavenger, peristaltic, pesticide, photosensitizer, sedative, transdermal

ACE-inhibitor, aldose-reductase-inhibitor, allergenic, analgesic, antibacterial, anticonvulsant, antimutagenic, antinitrosaminic, antinociceptive,; antioxidant, antispasmodic, chemopreventive; flavor; fungicide, hypothermic, insectifuge, irritant, myorelaxant, perfumery, pesticide

Antimicrobial 
Table 6 Total phenolic and flavonoid contents and antioxidant activity of different extracts from Schinus molle L. wood branch

\begin{tabular}{lllll}
\hline Extract & $\begin{array}{l}\text { Total phenolic } \\
(\text { mg TAE/g extract })\end{array}$ & $\begin{array}{l}\text { Total flavonoids } \\
(\text { mg CAE/g extract })\end{array}$ & TAA \% & $\mathrm{IC}_{50}(\mu \mathrm{g} / \mathrm{mL})^{\mathrm{a}}$ \\
\hline ME & $12.3 \pm 2.00 c$ & $50.70 \pm 1.80 a$ & $70 \pm 1.90 d$ & $228.66 \pm 1.12 b$ \\
Dichloromethane DCME & $25.1 \pm 2.50 b$ & $19.33 \pm 1.12 c$ & $30.02 \pm 0.12 e$ & $334.11 \pm 1.53 a$ \\
WE & $30.90 \pm 1.90 a$ & $30.30 \pm 1.13 b$ & $86.30 \pm 1.40 b$ & $12.66 \pm 2.15 e$ \\
EO & - & - & $90 \pm 1.23 a$ & $13.11 \pm 3.00 e$ \\
TA & - & - & $85 \pm 5.12 c$ & $24.70 \pm 0.48 d$ \\
CA & - & - & $84.13 \pm 1.90 c$ & $30.75 \pm 0.88 c$ \\
\hline
\end{tabular}

(-) Not applicable

Values with different letters within the same column were significantly different at the level of $p \leq 0.05$

All values are mean \pm standard deviation of three replicates

$T A A \%$ total antioxidant activity, TAE tannic acid equivalents, $C A E(+)$-catechin equivalents, $T A$ tannic acid, $C A(+)$-catechin, $M E$ methanol extract, $D C M E$ dichloromethane extract, $W E$ water extract, $E O$ essential oil

${ }^{a} \mathrm{IC}_{50}$ data expressed as $\mu \mathrm{g} / \mathrm{mL}$. Lower $\mathrm{IC}_{50}$ values indicated the highest radical scavenging activity

Table 7 Antibacterial activity of essential oil, methanol, dichloromethane, and water extracts from Schinus molle L. wood branch against some pathogenic bacteria

\begin{tabular}{|c|c|c|c|c|c|c|c|c|c|c|c|}
\hline \multirow[t]{2}{*}{ Bacteria } & \multicolumn{2}{|c|}{ Essential oil } & \multicolumn{2}{|c|}{ Methanol extract } & \multicolumn{2}{|c|}{$\begin{array}{l}\text { Dichloromethane } \\
\text { extract }\end{array}$} & \multicolumn{2}{|c|}{ Water extract } & \multirow[t]{2}{*}{$\begin{array}{l}\text { Negative } \\
\text { control }^{\mathrm{a}}\end{array}$} & \multicolumn{2}{|c|}{ Positive control $^{\mathrm{b}}$} \\
\hline & $\mathrm{IZ}(\mathrm{mm})$ & $\begin{array}{l}\text { MIC } \\
(\mu \mathrm{g} / \mathrm{mL})\end{array}$ & $\mathrm{IZ}(\mathrm{mm})$ & $\begin{array}{l}\text { MIC } \\
(\mu \mathrm{g} / \mathrm{mL})\end{array}$ & $\mathrm{IZ}(\mathrm{mm})$ & $\begin{array}{l}\text { MIC } \\
(\mu \mathrm{g} / \mathrm{mL})\end{array}$ & $\mathrm{IZ}(\mathrm{mm})$ & $\begin{array}{l}\mathrm{MIC} \\
(\mu \mathrm{g} / \mathrm{mL})\end{array}$ & & $\mathrm{IZ}(\mathrm{mm})$ & $\begin{array}{l}\mathrm{MIC} \\
(\mu \mathrm{g} / \mathrm{mL})\end{array}$ \\
\hline B. subtilis & $13 \pm 0.12$ & 250 & $15 \pm 1.12$ & 125 & $12 \pm 0.12$ & 125 & $18 \pm 1.12$ & 4 & NA & $25 \pm 1.33$ & 8 \\
\hline B. cereus & $12 \pm 0.00$ & 32 & $13 \pm 0.14$ & 32 & $10 \pm 1.33$ & 500 & $20 \pm 3.14$ & 32 & NA & $20 \pm 0.66$ & 8 \\
\hline S. aureus & $15 \pm 0.33$ & 64 & $15 \pm 1.33$ & 32 & $8 \pm 0.33$ & 1000 & $13 \pm 0.66$ & 8 & NA & $21 \pm 0.00$ & 16 \\
\hline E. coli & $14 \pm 0.00$ & 125 & $10 \pm 0.66$ & 250 & $8 \pm 0.00$ & 1000 & $15 \pm 0.33$ & 8 & NA & $22 \pm 0.00$ & 16 \\
\hline S. lutea & $12 \pm 0.15$ & 125 & $12 \pm 0.16$ & 1000 & $7 \pm 0.00$ & 1000 & $15 \pm 2.12$ & 4 & NA & $17 \pm 1.12$ & 8 \\
\hline P. aeruginosa & $12 \pm 0.00$ & 250 & NA & NA & NA & NA & $16 \pm 1.13$ & 32 & NA & $26 \pm 3.12$ & 8 \\
\hline M. luteus & $9 \pm 0.00$ & 500 & NA & NA & NA & NA & $14 \pm 0.33$ & 125 & NA & $20 \pm 0.00$ & 32 \\
\hline
\end{tabular}

Values of inhibition zones (IZs) are presented at the concentration of $200 \mu \mathrm{g} / \mathrm{mL}$

$N A$ not active, MIC minimum inhibitory concentration $(\mu \mathrm{g} / \mathrm{mL})$

${ }^{a}$ Disks were impregnated with $10 \%$ dimethyl sulfoxide (DMSO)

b $\mathrm{IZ}$ of tetracycline $(20 \mu \mathrm{g} / \mathrm{disk})$

Proteus vulgaris, Clostridium sporogenes, Acinetobacter calcoacetica, E. coli, Beneckea natriegens, Citrobacter freundii, S. marcescens, B. subtilis and Brochothrix thermosphacata [45]. Extracts from leaves, flowers and bark of Schinus molle L. displayed the strongest activity against both sensitive and resistant $S$. aureus strains (MIC between 62.5 and $250 \mu \mathrm{g} / \mathrm{mL}$ ) and the flower extracts were the most active [7]. Hexane extract from fruits of Schinus molle L. showed good antimicrobial activity against Streptococcus pneumoniae with $\mathrm{MIC}=62.5 \mu \mathrm{g} / \mathrm{mL}$ [46]. The aqueous extract of Schinus molle L. grown in Brazil, showed good antifungal activity against Candida albicans [47].

Elemol, a sesquiterpene, was isolated and identified from the EOs of Amyris balsamifera wood (Rutaceae) [48], and the oleoresin of Canarium zeylanicum bark and timber [49]. Elemol and p-cymene can be considered as the principal antimicrobial components of the EOs [50]. $\beta$-selinene, $\alpha$-elemol, and hinesol showed pronounced contact toxicity against Drosophila melanogaster adults [51].

Elemol was found to be as good, and, in some cases, better at repelling house flies (Musca domestica L.), and American cockroaches (Periplaneta americana L.), than $\mathrm{N}, \mathrm{N}$-diethyl-m-toluamide (DEET) or citronellal [52]. Phenolic compounds including simple phenolic such as EOs play a role in antioxidant activity in many species, consequently affecting the medicinal value of each plant part [53].

From all the above results, the identified chemical compounds from extracts of Schinus molle L. WB have been reported to possess various biological activities. Schinus molle L. is widely used in traditional medicine to 
treat a variety of diseases in countries other than Egypt. To date, no information is available on medicinal uses of Schinus molle L. WB from Egypt, and our study is the first study to show the biological activities of Schinus molle L. WB from Egypt.

\section{Conclusions}

In the present study, chemical components of essential oils, methanol, dichloromethane and water extracts from wood branch supplied from the tree pruning wastes of Schinus molle $\mathrm{L}$. were identified by GC-MS. The main constituents of the essential oils were $\alpha$-elemol, $\beta$-pinene, myrcene, $\alpha$ phellandrene, caryophyllene, $\alpha$-cadinol, cadinene, elixene, $\beta$-eudesmol, nerolidol, $\gamma$-eudesmol, and germacrene-D-4-ol. The major components in methanol extract were 6-(4chlorophenyl)-3-cyano-4-( $N$-benzylpiperazino)-2H-pyran2-one, 2-naphthalene methanol, decahydro- $\alpha, \alpha, 4 a-$ trimethyl-8-methylene and docosane, in dichloromethane extract were 12-methyl-E,E-3,13-octadecadien-1-ol, 1,2benzenedicarboxylic acid, dioctyl ester and acetic acid, (1,2,3,4,5,6,7,8-octahydro-3,8,8-trimethylnaphth-2-yl)

methyl ester, and in water extract were $\beta$-eudesmol, and (Z,Z,Z)-9,12,15-octadecatrienoic acid, 2,3-dihydroxypropyl ester.

The highest values of total phenolic contents were found in water extract, and the highest total flavonoid contents were found in methanol extract. The highest total antioxidant activity as measured by DPPH was found with essential oil $(90 \pm 1.23 \%)$ followed by water extract $(86.30 \pm 1.40 \%)$, and those values were higher than the values measured by tannic acid and $(+)$-catechin ( $85 \pm 5.12$, and $84.13 \pm 1.90$, respectively). The lowest $\mathrm{IC}_{50}$ value was $13.11 \pm 3.00 \mu \mathrm{g} / \mathrm{mL}$ (water extract) and $12.66 \pm 2.15 \mu \mathrm{g} / \mathrm{mL}$ (essential oil), and those values were lower than the $\mathrm{IC}_{50}$ of tannic acid and (+)-catechin $24.70 \pm 0.48$ and $30.75 \pm 0.88 \mu \mathrm{g} / \mathrm{mL}$, respectively). The MICs values of essential oils and water extract observed good antibacterial activity against the growth of the studied bacteria. This suggests that the essential oil as well as water extract of WBs have a potential effect for use in food and/or pharmaceutical industries. Several compounds have been identified from essential oil, methanol, dichloromethane and water extracts of Schinus molle L. wood branch by GC/MS analysis. Some of the identified compounds have been reported to possess various biological activities such as antioxidant, antimicrobial, anti-inflammatory, anticancer, antialdosteronic, antihepatotoxic, anti-inflammatory, antinociceptive, antiophidic, antiencephalopathic, antigastritic, antiprostatitic, antipruritic, and hypocholesterolemic. The presence of various bioactive compounds justifies the use of wood branches for various ailments by traditional practitioners. The yield of the essential oils from wood branch is $0.75 \mathrm{~mL} / 100 \mathrm{~g}$ fresh weight, while in our previous works, it was $0.40 \mathrm{~mL} / 100 \mathrm{~g}$ leaves fresh weight [35] and, from berries, was $4.26 \mathrm{~mL} / 100 \mathrm{~g}$ berries fresh weight (unpublished data) or $0.49 \% \mathrm{v} / \mathrm{w}$ from dried fruits $\left(36^{\circ} \mathrm{C}\right.$ in a forced air drier with humidity control) [54]. Therefore, we recommend using the wood branch of Schinus molle L. as bioresource for phytopharmaceutical importance. However, further studies need to be undertaken to ascertain fully its bioactivity.

Acknowledgments The authors would like to extend their sincere appreciation to the Deanship of Scientific Research at King Saud University for its funding this Research group NO. (RG 1435-011).

\section{References}

1. Wimalaratne P, Slessor K, Borden J, Chong L, Abate T (1996) Isolation and identification of house fly, Musca domestica L., repellents from pepper tree, Schinus molle L. J Chem Ecol 22:49-59

2. Taylor L (2005) The healing power of rainforest herbs. A guide to understanding and using herbal medicinals. Square One Publishers, New York

3. Hayouni EL, Chraief AI, Abedrabba M, Bouix M, Leveau JY, Mohammed H, Hamdi M (2008) Tunisian Salvia officinalis L. and Schinus molle L. essential oils: their chemical compositions and their preservative effects against Salmonella inoculated in minced beef meat. Int J Food Microbiol 125:242-251

4. Dikshit A, Naqvi AA, Husain A (1986) Schinus molle: a new source of natural fungitoxicant. Appl Environ Microbiol 51:1085-1088

5. Gundidza M (1993) Antimicrobial activity of essential oil from Schinus molle Linn. Cent Afr J Med 39:231-234

6. Murray A, Gurovic M, Rodriguez S, Murray M, Ferrero A (2009) Cetylcholinesterase inhibition and antioxidant activity of essential oils from Schinus areira L. and Schinus longifolia (Lindl.) Speg. Nat Prod Commun 4:873-876

7. Salazar-Aranda R, Pérez-López LA, López-Arroyo J, AlanísGarza BA, Torres NW (2011) Antimicrobial and antioxidant activities of plants from Northeast of Mexico. Evid Based Complement Alternat Med 536139:6

8. Tsuruta K, Yoshida Y, Kusumoto N, Sekine N, Ashitani T, Takahashi K (2011) Inhibition activity of essential oils obtained from Japanese trees against Skeletonema costatum. J Wood Sci 57:520-525

9. Pérez-López A, Cirio AT, Rivas-Galindo VM, Aranda RS, de Torres NW (2011) Activity against Streptococcus pneumoniae of the essential oil and $\delta$-cadinene isolated from Schinus molle fruit. J Essent Oil Res 23:25-28

10. Ruffa MJ, Ferraro G, Wgner ML, Calcagno ML, Campos RH, Cavallaro L (2002) Cytotoxic effect of Argentine medicinal plant extracts on human hepatocellular carcinoma cell line. J Ethnopharmacol 79:335-339

11. Yueqin Z, Recio MC, Mánez S, Giner RM, Cerdá-Nicolás M, Ríos J (2003) Isolation of two triterpenoids and a biflavanone with anti-inflammatory activity from Schinus molle fruits. Planta Med 69:893-898

12. Schmourlo G, Mendonça-Filho RR, Alviano CS, Costa SS (2005) Screening of antifungal agents using ethanol precipitation and 
bioautography of medicinal and food plants. J Ethnopharmacol 96:563-568

13. Duke JA (2007) Phytochemical and ethnobotanical databases. http://www.ars-grin.gov/duke/chem-activities.Html. Accessed 27 Jan 2006

14. Silva-Júnior EF, Aquino PGV, Santos-Júnior PFS, Nascimento IJS, Gomes EA, Silva ALL, Verissimo RCSS, Aquino TM, Araújo-Júnior JX (2015) Phytochemical compounds and pharmacological properties from Schinus molle Linnaeus and Schinus terebinthifolius Raddi (Anacardiaceae). J Chem Pharm Res 7:389-393

15. Ennigrou A, Hosni K, Casabianca H, Vulliet E, Smiti S (2011) Leaf volatile oil constituents of Schinus terebinthifolius and Schinus molle from Tunisia. In: Conference proceedings of the 6th baltic conference on food science and technology FOODBALT-2011, Jelgava, Latvia, 5-6 May, 2011. Innovations for food science and production. Latvia University of Agriculture, Jelgava, pp 90-92

16. Baser KHC, Kürkçüoglu M, Demirçakmak B, Uülker N, Beis SH (1997) Composition of the essential oil of Schinus molle L. grown in Turkey. J Essent Oil Res 9:693-696

17. Rossini C, Menéndez P, Dellacassa E, Moyna P (1996) Essential oils from leaves of Schinus molle and Schinus lentiscifolius of Uruguayan origin. J Essent Oil Res 8:71-73

18. Barroso MST, Villanueva G, Lucas AM, Perez GP, Vargas RMF, Brun GW, Cassel E (2011) Supercritical fluid extraction of volatile and non-volatile compounds from Schinus molle L. Braz J Chem Eng 28:305-312

19. Davies NW (1990) Gas chromatographic retention indices of monoterpenes and sesquiterpenes on methyl silicone and Carbowax $20 \mathrm{M}$ phases. J Chromatogr A 503:1-24 (British Pharmacopeia 1998, Vol. II, HMSO, London)

20. Adams RP (2007) Identification of essential oil components by gas chromatography/mass spectroscopy, 4th edn. Allured Publishing, Carol Stream, p 804 (ISBN:13-9781932633214)

21. Wiley NIST (2008) The Wiley/NBS registry of mass spectral data, 8th edn. Wiley, New York

22. Marinova D, Ribarova F, Atanassova M (2005) Total phenolics and total flavonoids in Bulgarian fruits and vegetables. J Univ Chem Tech Metall 40:255-260

23. Batubara I, Mitsunaga T, Ohashi H (2009) Screening antiacne potency of Indonesian medicinal plants: antibacterial, lipase inhibition, and antioxidant activities. J Wood Sci 55:230-235

24. Fejes S, Blzovics A, Lugasi A, Lemberkovics E, Petri G, Kry A (2000) In vitro antioxidant activity of Anthriscus cerefolium L. (Hoffm.) extracts. J Ethnopharmacol 69:259-265

25. Bauer AW, Kirby WM, Sherris JC, Turck M (1966) Antibiotic susceptibility testing by a standardized single disk method. Am J Clin Pathol 45:493-496

26. Tanaka A, Kim HJ, Kuniyoshi SO, Kondo SR (2011) Antibacterial activity of moso bamboo shoot skin (Phyllostachys pubescens) against Staphylococcus aureus. J Wood Sci 57:542-544

27. Bernhard RA, Shibamoto T, Yamaguchi K, White E (1983) The volatile constituents of Schinus molle L. J Agric Food Chem 31:463-466

28. Lawrence B (1984) A discussion of Schinus molle and Schinus terebinthifolius. Flavour Frag J 9:65-69

29. Maffei M, Chialva F (1990) Essential oils from Schinus molle L. berries and leaves. Flavour Frag J 5:49-52

30. Bendaoud H, Romdhane M, Souchard JP, Cazaux S, Bouajila J (2010) Chemical composition and anticancer and antioxidant activities of Schinus molle L. and Schinus terebinthifolius Raddi berries essential oils. J Food Sci 75:466-472

31. Zahed N, Hosni K, Brahim NB, Kallel M, Sebei H (2010) Allelopathic effect of Schinus molle essential oils on wheat germination. Acta Physiol Plant 32:1221-1227
32. Martins MDR, Arantes S, Candeias F, Tinoco MT, Cruz-Morais J (2013) Antioxidant, antimicrobial and toxicological properties of Schinus molle L. essential oils. J Ethnopharmacol 151:485-492

33. Díaz C, Quesada S, Brenes O, Aguilar G, Cicció JF (2008) Chemical composition of Schinus molle essential oil and its cytotoxic activity on tumour cell lines. Nat Prod Res 22:1521-1534

34. Abdel-Sattar E, Zaitoun AA, Farag MA, El Gayed SH, Harraz FM (2010) Chemical composition, insecticidal and insect repellent activity of Schinus molle L. leaf and fruit essential oils against Trogoderma granarium and Tribolium castaneum. Nat Prod Res 24:226-235

35. Salem MZM, El-Shikh MS, Ali HM (2013) Chemical characterization of the volatile oil isolated from leaves of Schinus molle L. and its antioxidant activity. J Pure Appl Microbiol 7:355-360

36. Guerra-Boone L, Alvarez-Román R, Salazar-Aranda R, TorresCirio A, Rivas-Galindo VM, Waksman N, de Torres GM, González G, Pérez-López LA (2013) Chemical compositions and antimicrobial and antioxidant activities of the essential oils from Magnolia grandiflora, Chrysactinia mexicana, and Schinus molle found in northeast Mexico. Nat Prod Commun 8:135-138

37. Bandoni A (2000) Los recursos vegetales aromáticos en latinoamérica: su aprovechamiento industrial para la producción de aromas y sabores (in Spanish). CYTED, La Plata, Argentina, pp 263-284

38. Benzi V, Stefanazzi N, Ferrero AA (2009) Biological activity of essential oils from leaves and fruits of pepper tree (Schinus molle L.) to control rice weevil (Sitophilus oryzae L.). Chil J Agric Res 69:154-159

39. Atale N, Rani N (2013) GC-MS analysis of bioactive components in the ethanolic and methanolic extract of Syzygium cumini. Int J Pharm Bio Sci 4:296-304

40. Saidana D, Mahjoub MA, Boussaada O, Chriaa J, Chéraif I, Daami M, Mighri Z, Helal AN (2008) Chemical composition and antimicrobial activity of volatile compounds of Tamarix boveana (Tamaricaceae). Microbiol Res 163:445-455

41. Bharathy V, Uthayakumar F (2013) Bioactive components in leaves of Jatropha tanjorensis J.L. Ellis \& Saroja by GC-MS Analysis. Int J Pharm Tech Res 5:1839-1843

42. Guala MS, Elder HV, Perez G, Chiesa A (2009) Evaluación del poder antioxidante de fracciones de aceite esencial crudo de Schinus molle L. obtenidas por destilación al vacío. Inf Tecnol 20:83-88

43. Machado DG, Bettio LEB, Cunha MP, Santos ARS, Pizzolatti MG, Brighente IMC, Rodrigues ALS (2008) Antidepressant-like effect of rutin isolated from the ethanolic extract from Schinus molle L. in mice: evidence for the involvement of the serotonergic and noradrenergic systems. Eur J Pharmacol 587:163-168

44. Ojeda-Sana AM, Van Baren CM, Elechosa MA, Juárez MA, Moreno S (2013) New insights into antibacterial and antioxidant activities of rosemary essential oils and their main components. Food Control 31:189-195

45. Gundidza M (1993) Antimicrobial activity of essential oil from Schinus molle Linn. Cent Afr J Med 39:231-234

46. Molina-Salinas GM, Pérez-López A, Becerril-Montes P, SalazarAranda R, Said-Fernández S, de Torres NW (2007) Evaluation of the flora of Northern Mexico for in vitro antimicrobial and antituberculosis activity. J Ethnopharmacol 109:435-441

47. Schomourlo G, Mendonça-Fiho RR, Alviano CS, Costa SS (2005) Screening of antifungal agents using ethanol precipitation and bio-autography of medicinal and food plants. J Ethnopharmacol 96:563-568

48. Rohmer M, Schwartz AC, Anton R (1977) Sesquiterpenes from essential oil of Amyris balsamifera. Phytochemistry 16:773-774

49. Bandaranayake WM (1980) Terpenoids of Canarium zeylanicum. Phytochemistry 19:255-257 
50. Mevy JP, Bessiere JM, Dherbomez M, Millogo J, Viano J (2007) Chemical composition and some biological activities of the volatile oils of a chemotype of Lippia chevalieri Moldenke. Food Chem 101:682-685

51. Chu SS, Jiang GH, Liu ZL (2011) Insecticidal compounds from the essential oil of Chinese medicinal herb Atractylodes chinensis. Pest Manag Sci 67:1253-1257

52. Schultz G, Simbro E, Belden J, Zhu J, Coats J (2004) Catnip, Nepeta cataria (Lamiales: Lamiaceae)—A closer look: seasonal occurrence of nepetalactone isomers and comparative repellency of three terpenoids to insects. Environ Entomol 33:1562-1569
53. Craft BD, Kerrihard AL, Amarowicz R, Pegg RB (2012) Phenolbased antioxidants and the in vitro methods used for their assessment. Compr Rev Food Sci Saf 11:148-173

54. dos Santos ACA, Rossato M, Agostini F, Serafini LA, dos Santos PL, Molon R, Dellacassa E, Moyna P (2009) Chemical composition of the essential oils from leaves and fruits of Schinus molle L. and Schinus terebinthifolius Raddi from Southern Brazil. J Essent Oil Bear Pl 12:16-25 